\title{
Implementasi Wawasan Nusantara dalam Bermasyarakat
}

Sheren Mega Fitri Ananda

\author{
IIK STRADA Indonesia
}

\author{
sherengafida@gmail.com
}

\begin{abstract}
Abstrak
Akankah wawasan bangsa Indonesia tentang persatuan kesatuan itu larut atau hanyut tanpa bekas atau akan tetap kokoh dan mampu bertahan dalamterpaan dan gempuran nilai global yang menantang Wawasan Persatuan Bangsa Indonesia antara lain pemberdayaan rakyat yang optimal, dunia tanpa batas, serta era baru kapitalisme dan kesadaran warga negara. Saat ini kita menyaksikan bahwa kehidupan manusia baik secara individu dalam bermasyarakat, berbangsa dan bernegara semuanya sedang mengalami suatu proses perubahan dan kita juga menyadari bahwa faktor yang mendorong terjadinya proses perubahan tersebut adalah nilainilai kehidupan baru yang dibawakan oleh negara-negara maju dengan kekuatan penetrasi globalnya. Wawasan nusantara merupakan suatu hal yang sangat penting untuk dimiliki oleh generasi muda karena mampu mempererat persatuan, mencegah konflik dan memupuk rasa toleransi. Karena hal itu, penulis ingin meneliti bagaimana dampak dari wawasan nusantara

jika diimplementasikan dalam kehidupan bermasyarakat dan segi apa saja yang akan merasakan dampaknya.
\end{abstract}

\section{Kata Kunci : Implementasi, Wawasan Nusantara, Bermasyarakat}

\section{Latar Belakang}

Suatu bangsa yang besar akan mengalami kejayaan jika penduduknya mampu mengimplementasikan wawasan nusantara dalam semua aktivitas bermasyarakat. Implementasi atau penerapan wawasan nusantara harus tercermin pada pola piker, pola sikap, dan pola tindak yang senantiasa mendahulukan kepentingan bangsa dan negara daripada kepentingan pribadi atau kelompok. Dengan kata lain, wawasan nusantara menjadi pola yang mendasari cara berpikir,bersikap, dan bertindak dalam rangka menghadapi berbagai masalah menyangkut kehidupan bermasyarakat, berbangsa dan bernegara. Implementasi wawasan nusantara bertujuan untuk menerapkan wawasan nusantara dalam kehidupan sehari. Dengan adanya implementasi Wawasan nusantara merupakan suatu hal yang sangat penting untuk dimiliki oleh generasi muda karena mampu mempererat persatuan, mencegah konflik dan memupuk rasa toleransi.

Dewasa ini kita menyaksikan bahwa kehidupan manusia baik secara individu dalam bermasyarakat, berbangsa dan bernegara semuanya sedang mengalami suatu proses perubahan dan kita juga menyadari bahwa faktor yang mendorong terjadinya proses perubahan tersebut adalah nilai-nilai kehidupan baru yang dibawakan oleh negara-negara maju dengan kekuatan penetrasi globalnya. 
Akankah wawasan bangsa Indonesia tentang persatuan kesatuan itu larut atau hanyut tanpa bekas atau akan tetap kokoh dan mampu bertahan dalamterpaan dan gempuran nilai global yang menantang Wawasan Persatuan Bangsa Indonesia antara lain pemberdayaan rakyat yang optimal, dunia tanpa batas, serta era baru kapitalisme dan kesadaran warga negara. Oleh karena itu, pentingnya pemahaman wawasan nusantara dalam kehidupan bermasyarakat penduduknya.

\section{Kasus / Masalah}

Melihat keadaan saat ini banyak negara yang sedang mengalami fase perubahan maka, masalah yang akan penulis angkat adalah "Bagaimana dampak yang dihasilkan jika wawasan nusantara bisa diimplementasikan pada kehidupan bermasyarakat?"

\section{Tinjauan Pustaka}

\subsection{Implementasi}

\subsubsection{Pengertian Implementasi}

Implementasi adalah suatu tindakan atau pelaksanaan dari sebuah rencana yang sudah disusun secara matang dan terperinci. Implementasi biasanya dilakukan setelah perencanaan sudah dianggap sempurna. Menurut Nurdin Usman, implementasi adalah bermuara pada aktivitas, aksi, tindakan atau adanya mekanisme suatu sistem, implementasi bukan sekedar aktivitas, tapi suatu kegiatan yang terencana dan untuk mencapai tujuan kegiatan.

Menurut Purwanto dan Sulistyastuti, Implementasi intinya adalah kegiatan untuk mendistribusikan keluaran kebijakan (to deliver policy output) yang dilakukan oleh para implementor kepada kelompok sasaran (target group) sebagai upaya untuk mewujudkan kebijakan.

Implementasi juga bisa berarti pelaksanaan yang berasal dari kata bahasa Inggris Implement yang berarti melaksanakan. Bahwa dapat disimpulkan implementasi ialah suatu kegiatan yang terencana, bukan hanya suatu aktifitas dan dilakukan secara sungguh-sungguh berdasarkan acuan normanorma tertentu untuk mencapai tujuan kegiatan. Oleh karena itu, impelementasi tidak berdiri sendiri tetapi dipengaruhi oleh objek berikutnya yaitu kurikulum. Implementasi kurikulum merupakan proses pelaksanaan ide, program atau aktivitas baru dengan harapan orang lain dapat menerima dan melakukan perubahan terhadap suatu pembelajaran dan memperoleh hasil yang diharapkan.

\subsubsection{Faktor-Faktor yang Mempengaruhi Implementasi}

Keberhasilan implementasi menurut Merile S. Grindle dipengaruhi oleh dua variabel besar, yakni isi kebijakan (content of policy) dan lingkungan implementasi (context of implementation). Variabel isi kebijakan ini mencangkup:

1) sejauh mana kepentingan kelompok sasaran termuat dalam isi kebijakan.

2) jenis manfaat yang diterima oleh target group.

3) Sejauh mana perubahan yang diinginkan dari sebuah kebijakan.

4) Apakah letak sebuah program sudah tepat.

Variabel lingkungan kebijakan mencakup: 
a. Seberapa besar kekuasaan, kepentingan, dan strategi yang dimiliki oleh para actor yang terlibat dalam implementasi kebijakan.

b. Karakteristik institusi dan rejim yang sedang berkuasa.

c. Tingkat kepatuhan dan responsivitas kelompok sasaran.

\subsection{Wawasan Nusantara}

\subsubsection{Pengertian Wawasan Nusantara}

\section{Menurut Prof.Dr. Wan Usman}

Wawasan Nusantara adalah cara pandang bangsa Indonesia mengenai diri dantanah air nya sebagai Negara kepulauan dengan semua aspek kehidupan yang beragam.

\section{Menurut Kelompok Kerja LEMHANAS 1999}

Wawasan Nusantara adalah cara pandang dan sikap bangsa Indonesiamengenai diri dan lingkungannya yang beragam dan bernilai strategis denganmengutamakan persatuan dan kesatuan bangsa dan kesatuan wilayah dalammenyelenggarakan kehidupan bermasyarakat, berbangsa dan bernegara untukmencapai tujuan nasional.

\section{Menurut Ketetapan MPR Tahun 1993 dan 1998 Tentang GBHN}

Wawasan Nusantara adalah cara pandang dan sikap bangsa Indonesiamengenai diri dan lingkungannya dengan mengutamakan persatuan dankesatuan bangsa serta kesatuan wilayah dalam menyelenggarakan kehidupan bermasyarakat, berbangsa, dan bernegara untuk mencapai tujuan nasional.

\subsubsection{Isi Wawasan Nusantara}

\section{Perwujudan Kepulauan Nusantara sebagai Satu Kesatuan Politik,berarti}

a. Bahwa kebulatan wilayah nasional dengan segala isi dan kekayaannyamerupakan satu kesatuan wilayah, wadah, ruang hidup, dan kesatuanmatra seluruh bangsa serta menjadi modal dan milik bersama bangsa.

b. Bahwa bangsa Indonesia yang terdiri dari berbagai suku dan berbicaradalam berbagai bahasa daerah serta memeluk dan meyakini berbagaiagama dan kepercayaan terhadap Tuhan Yang Maha Esa harusmerupakan satu kesatuan bangsa yang bulat dalam arti yang seluasluasnya.

c. Bahwa secara psikologis, bangsa Indonesia harus merasa satu, senasibsepenanggungan, sebangsa, dan setanah air, serta mempunyai tekaddalam mencapai cita-cita bangsa.

d. Bahwa Pancasila adalah satu-satunya falsafah serta ideologi bangsa dannegara yang melandasi, membimbing, dan mengarahkan bangsa menujutujuannya.Bahwa kehidupan politik di seluruh wilayah Nusantara merupakan satukesatuan politik yang diselenggarakan berdasarkan Pancasila danUndang-Undang Dasar 1945. 
e. Bahwa seluruh Kepulauan Nusantara merupakan satu kesatuan sistemhukum dalam arti bahwa hanya ada satu hukum nasional yangmengabdi kepada kepentingan nasional.

f. Bahwa bangsa Indonesia yang hidup berdampingan dengan bangsa lainikut menciptakan ketertiban dunia yang berdasarkan kemerdekaan, perdamaian abadi, dan keadilan sosial melalui politik luar negeri bebasaktif serta diabdikan pada kepentingan nasional.

2. Perwujudan Kepulauan Nusantara sebagai satu Kesatuan Ekonomi, berarti:

a. Bahwa kekayaan wilayah Nusantara baik potensial maupun efektifadalah modal dan milik bersama bangsa, dan bahwa keperluan hidupsehari-hari harus tersedia merata di seluruh wilayah tanah air. b. Tingkat perkembangan ekonomi harus serasi dan seimbang di seluruhdaerah, tanpa meninggalkan ciri khas yang dimiliki oleh daerah dalam pengembangan kehidupan ekonominya.

c.Kehidupan perekonomian di seluruh wilayah Nusantara merupakan satukesatuan ekonomi yang diselenggarakan sebagai usaha bersama atasasas kekeluargaan dan ditujukan bagi sebesar-besar kemakmuranrakyat.

\section{Perwujudan Kepulauan Nusantara sebagai Satu Kesatuan Sosial danBudaya, berarti:}

a. Bahwa masyarakat Indonesia adalah satu, perikehidupan bangsa harusmerupakan kehidupan bangsa yang serasi dengan terdapatnya tingkatkemajuan masyarakat yang sama, merata dan seimbang, serta adanyakeselarasan kehidupan yang sesuai dengan tingkat kemajuan bangsa.

b. Bahwa budaya Indonesia pada hakikatnya adalah satu, sedangkan corakragam budaya yang ada menggambarkan kekayaan budaya bangsa yangmenjadi modal dan landasan pengembangan budaya bangsa seluruhnya,dengan tidak menolak nilai-nilai budaya lain yang tidak bertentangandengan nilai budaya bangsa, yang hasil-hasilnya dapat dinikmati oleh bangsa.

\section{Perwujudan Kepulauan Nusantara sebagai Satu Kesatuan PertahananKeamanan, bearti :}

a. Bahwa ancaman terhadap satu pulau atau satu daerah pada hakekatnyamerupakan ancaman terhadap seluruh bangsa dan negara. b. Bahwa tiap-tiap warga negara mempunyai hak dan kewajiban yangsama dalam rangka pembelaan negara dan bangsa.

\section{Pembahasan}

Implementasi atau penerapan wawasan nusantara harus tercermin pada pola piker, pola sikap, dan pola tindak yang senantiasa mendahulukan kepentingan bangsa dan negara daripada kepentingan pribadi atau kelompok. Dengan kata lain, wawasan nusantara menjadi pola yang mendasari cara berpikir,bersikap, dan bertindak dalam rangka menghadapi berbagai masalah menyangkut kehidupan bermasyarakat, berbangsa dan bernegara. Implementasi wawasan nusantara bertujuan untuk menerapkan wawasan nusantara dalam kehidupan sehari.

\section{Implementasi wawasan nusantara dalam bidang ekonomi}


Dalam bidang ekonomi, implementasi wawasan nusantara akanmenciptakan tatanan ekonomi yang benar-benar menjamin pemenuhan dan peningkatan kesejahteraan dan kemakmuran rakyat secara adil dan merata.Di samping itu, juga dapat mencerminkan tanggung jawab pengelolaansumber daya alam yang memperhatikan kebutuhan masyarakat antar daerah secara timbal balik serta kelestarian sumber daya alam itusendiri. Prinsip-prinsip implementasi wawasan nusantara dalam bidangekonomi yaitu:

a. Kekayaan di wilayah nusantara, baik potensial maupun efektif, adalahmodal dan milik bersama bangsa untuk memenuhi kebutuhan di seluruhwilayah Indonesia secara merata.

b. Tingkat perkembangan ekonomi harus serasi dan seimbang di seluruhdaerah tanpa meninggalkan ciri khas yang dimiliki oleh daerah masing-masing dalam pengembangan kehidupan ekonominya.

c. Kehidupan perekonomian di seluruh wilayah nusantara diselenggarakansebagai usaha bersama dengan asas kekeluargaan dalam sistemekonomi kerakyatan untuk kemakmuran rakyat yang sebesar-besarnya.Contoh implementasi wawasan nusantara dalam bidang ekonomidiantaranya dengan menyeimbangkan Keuangan Pusat dan Daerahdengan keluarnya Undang-Undang No. 25 Tahun 1999 tentangPerimbangan Keuangan Antara Pusat dan Daerah. Pembagian keuanganyang semula hampir $80 \%$ anggaran daerah harus menunggudidatangkan dari pusat, padahal $90 \%$ hasil-hasil daerah diserahkan pada pemerintahan pusat, kini pada UU tersebut diubah menjadi :

a) Hasil Pajak Bumi dan Bangunan, 10\% untuk pemerintah pusat dan90\% untuk daerah.

b) Hasil Bea Perolehan Hak atas Tanah dan Bangunan, 20\% untuk pusat, $80 \%$ untuk daerah.

c) Hasil kehutanan, pertambangan umum dan perikanan, $20 \%$ untuk pusat dan $80 \%$ untuk daerah.

d) Hasil minyak bumi, $85 \%$ untuk pusat, $15 \%$ untuk daerah dan gasalam, $70 \%$ untuk pusat dan $30 \%$ untuk daerah.

\section{Implementasi wawasan nusantara dalam bidang politik}

Ada beberapa hal yang perlu diperhatikan dalam mengimplementasikanwawasan nusantara, yaitu:

a. Pelaksanaan kehidupan politik yang diatur dalam undang-undang,seperti UU Partai Politik, UU Pemilihan Umum, dan UU PemilihanPresiden.Pelaksanaan undang-undang tersebut harus sesuai hukum danmementingkan persatuan bangsa. Contohnya seperti dalampemilihan presiden, anggota DPR, dan kepala daerah harus menjalankan pri nsipdemokratis dan keadilan, sehingga tidak menghancurkan persatuan dankesatuan bangsa.

b. Pelaksanaan kehidupan bermasyarakat dan bernegara di Indonesiaharus sesuai denga hukum yang berlaku. Seluruh bangsa Indonesiaharus mempunyai dasar hukum yang sama bagi setiap warga negara,tanpa pengecualian. Di Indonesia terdapat banyak produk hukum yangdapat diterbitkan oleh provinsi dan kabupaten dalam bentuk peraturandaerah (perda) yang tidak bertentangan dengan hukum yang berlakusecara nasional.

c. Mengembangkan sikap hak asasi manusia dan sikap pluralisme untukmempersatukan berbagai suku, agama, dan bahasa yamg berbeda,sehingga menumbuhkan sikap toleransi. 
d. Memperkuat komitmen politik terhadap partai politik dan lembaga pemerintahan untuk menigkatkan semangat kebangsaan dan kesatuan

e. Meningkatkan peran Indonesia dalam kancah internasional danmemperkuat korps diplomatik ebagai upaya penjagaan wilayahIndonesia terutama pulau-pulau terluar dan pulau kosong.

\section{Implementasi wawasan nusantara dalam kehidupan sosial}

Beberapa hal yang perlu diperhatikan dalam kehidupan sosial, yaitu:

a. Mengembangkan kehidupan bangsa yang serasi antara masyarakatyang berbeda, dari segi budaya, status sosial, maupun daerah.Contohnya dengan pemerataan pendidikan di semua daerah dan program wajib belajar harus diprioritaskan bagi daerah tertinggal.

b. Pengembangan budaya Indonesia, untuk melestarikan kekayaanIndonesia, serta dapat dijadikan kegiatan pariwisata yang memberikan sumber pendapatan nasional maupun daerah. Contohnya dengan pelestarian budaya, pengembangan museum, dan cagar budaya.

\section{Implementasi wawasan nusantara dalam kehidupan pertahanan dan keamanan}

Beberapa hal yang perlu diperhatikan dalam kehidupan pertahanan dankeamanan, yaitu:

a. Kegiatan pembangunan pertahanan dan keamanan harus memberikankesempatan kepada setiap warga negara untuk berperan aktif, karenakegiatan tersebut merupakan kewajiban setiap warga negara, sepertimemelihara lingkungan tempat tinggal, meningkatkan kemampuandisiplin, melaporkan hal-hal yang menganggu keamanan kepada aparatdan belajar kemiliteran.

b. Membangun rasa persatuan, sehingga ancaman suatu daerah atau pulau juga menjadi ancaman bagi daerah lain. Rasa persatuan ini dapatdiciptakan dengan membangun solidaritas dan hubungan erat antarawarga negara yang berbeda daerah dengan kekuatan keamanan.

c. Membangun TNI yang profesional serta menyediakan sarana dan prasarana yang memadai bagi kegiatan pengamanan wilayahIndonesia,

\section{Kesimpulan} terutama pulau dan wilayah terluar Indonesia.

Dewasa ini kita menyaksikan bahwa kehidupan manusia baik secara individu dalam bermasyarakat, berbangsa dan bernegara semuanya sedang mengalami suatu proses perubahan dan kita juga menyadari bahwa faktor yang mendorong terjadinya proses perubahan tersebut adalah nilai-nilai kehidupan baru yang dibawakan oleh negara-negara maju dengan kekuatan penetrasi globalnya. Melihat banyaknya tantangan yang dihadapi oleh generasi saat ini perlu adanya pegangan hidup bernegara yaitu implementasi wawasan nusantara. Implementasi atau penerapan wawasan nusantara harus tercermin pada pola piker, pola sikap, dan pola tindak yang senantiasa mendahulukan kepentingan bangsa dan negara daripada kepentingan pribadi atau kelompok. Dengan kata lain, wawasan nusantara menjadi pola yang mendasari cara berpikir,bersikap, dan bertindak dalam rangka menghadapi berbagai masalah menyangkut kehidupan bermasyarakat, berbangsa dan bernegara. Implementasi wawasan nusantara bertujuan untuk menerapkan wawasan nusantara dalam kehidupan sehari. Dengan adanya implementasi Wawasan nusantara merupakan suatu hal yang sangat penting untuk dimiliki oleh generasi muda karena mampu mempererat persatuan, mencegah konflik dan memupuk rasa toleransi. 


\section{Daftar Pustaka}

Ananda, S. M. F. (2021, October 29). Persatuan dan Kesatuan dalam Rasa Bhinneka Tunggal Ika Melawan Pandemi Covid 19.

E. Mulyasa, Implementasi Kurikulum Tingkat Satuan Pendidikan, Jakarta, Bumi Aksara, 2013, Hal. 56.

Guntur Setiawan, Impelemtasi dalam Birokrasi Pembangunan, Balai Pustaka, Jakarta, 2004, Hal. 39.

Karina, Z., \& Sodik, M. A. (2018). Pengaruh Dukungan Sosial Terhadap Kesehatan.

Merile S. Grindle (Dalam Buku Budi Winarno). Teori dan Proses Kebijakan Publik, Media Pressindo, Yogyakarta, 2002, Hal. 21.

Nurdin Usman, Konteks Implementasi Berbasis Kurikulum,Grasindo, Jakarta, 2002, Hal. 70 .

Purwanto dan Sulistyastuti, Analisis Kebijakan dari Formulasi ke Implementasi Kebijakan, Bumi Aksara Jakarta, 1991, Hal. 21. 